\title{
Initiation of Primary Cell Cultures from Embryos of the Mosquitoes Anopheles albimanus and Aedes taeniorhynchus (Diptera: Culicidae)
}

\author{
Felio J Bello García, Jorge Boshell*, Gloria Rey*, Alberto Morales*, \\ Victor Alberto Olano*
}

\author{
Departamento de Biología y Química, Universidad de La Salle, Carrera 2 No 10-70, Santafé de Bogotá, \\ Colombia *Instituto Nacional de Salud, Laboratorios de Virología y Entomología, \\ Apartado Aéreo 80080, Santafé de Bogotá, Colombia
}

\begin{abstract}
Primary cell cultures were obtained from eggs of Anopheles albimanus and Aedes taeniorhynchus mosquitoes, vectors of human malaria and of Venezuelan equine encephalitis virus, respectively. The cellular growth of the An. albimanus cells began four weeks after explanting the embryonic tissues in MKIVP12 medium, supplemented with $15 \%$ fetal bovine serum. The culture showed heterogeneous cellular morphology. With regard to the Ae. taeniorhynchus culture, cellular growth occurred three weeks after initiating the culture in MMNVPI2 medium. The majority of cells were small and round. Karyotypes were examined in the latter species.
\end{abstract}

Key words: mosquitoes - cell cultures - culture media - karyotype

Anopheles albimanus (Wiedemann 1820) and Aedes taeniorhynchus (Wiedemann 1821) are mosquitoes of epidemiological interest because they are important vectors of human malaria and Venezuelan equine encephalitis, respectively. Many genetic, physiological, toxicological, and viral susceptibility studies are undertaken with mosquito cell cultures more easily than with whole organisms. Cell cultures have several advantages over colonies of the whole organism in that they can be grown on defined media, occupy little space, require few environmental controls, and, most importantly, can be stored indefinitely in liquid nitrogen (Munstermann 1994).

Primary cultures are generally obtained from pieces of animal tissues from which dividing cells migrate and adhere to an artificial substratum. Alternatively mechanical or enzymatic separation of the tissues can produce a suspension of cells which eventually adhere to the substratum to form a monolayer (Freshney 1987).

The first mosquito cell line was established by Grace (1966). Later, Singh (1967) established two cell lines, one from the mosquito Ae. aegypti and the other one from the mosquito Ae. albopictus. Igarashi (1978) developed a clone (C6/36) from Singh's original $A e$. albopictus cell line that has

Work supported by COLCIENCIAS and Ia Salle University as well as Colombian National Institute of Health.

Received 17 de August 1994

Accepted 5 May 1995 been used traditionally for dengue and other virus research. Working with different mosquito species, other cell lines have been established (Schneider 1969, Varma \& Pudney 1969, Hsu et al. 1970, 1972, Varma et al. 1974, Cahoon et al. 1978, Tesh 1980, Oro 1984, Rowley et al. 1984, Oelofsen et al. 1990), which have also been used in virological studies. Insect cell lines have been used to isolate and identify arboviruses, to study insecticide resistance, to prepare antigens, to develop basic studics of biological cycles and to support baculovinus growth in molecular biology studies (Igararashi 1985, Kuno et al. 1985, Sieburth \& Maruniak 1988).

The present study describes, for the first time, the development of primary cell cultures of $A n$. albimanus and Ae. taeniorhynchus from embryonic tissues. The cells of both cultures are described morphologically and a karyologic study of the $A e$. taeniorhynchus was carried out.

\section{MATERIALS AND METHODS}

Colonies of mosquitoes - Adult An. albimanus and Ae. taeniorhynchus mosquitoes were collected from their natural environment, in regions close to the cities of Barranquilla (Atlantico) and Cartagena (Bolivar), Colombia, in November 1992 and April 1993, respectively. Colonies were established and maintained in the insectary of the National Institute of Health in Santafé de Bogotá, D.C., Colombia.

Sterilization of the specimens - Embryonated eggs of both mosquito species were collected and 
inmersed in tubes of water. The water was removed with a Pasteur pipette, leaving the eggs; a $1.6 \%$ solution of sodium hypochlorite was added for 10 min. During this period the tubes were stirred repeatedly; then, the hypochlorite solution was removed and $70 \%$ ethanol was added, stirring continuously for $10 \mathrm{~min}$. Finally, the eggs were washed three times with sterile distilled water (Tesh 1980).

Initiation of primary cultures - After sterilization, the embryonated eggs were rinsed with the culture medium to be used. One $\mathrm{ml}$ of egg mass was placed into a $2 \mathrm{ml}$ Ten Broek homogenizer where the eggs were broken mechanically. The resultant suspension was placed in a $25 \mathrm{~cm}^{2}$ plastic tissue culture flask containing $5 \mathrm{ml}$ of the growth medium. The cells were maintained in an incubator at $28^{\circ} \mathrm{C}$. The culture was inspected daily with an inverted microscope.

Culture media - The seeding of embryonic tissues of both species of mosquitoes was carried out separately in the following culture media: MEM (Gibco), L-15 (Gibco), MM (Mitsuhashi \& Maramorosch 1964), VP12 (Varma \& Pudney 1969), MK (Kitamura 1970) and MK/VP 12 (Varma \& Pudney 1971). Fetal bovine serum (15\%), penicillin (100 units/ml) and streptomicin $(100 \mu \mathrm{g} / \mathrm{ml})$ were added to each of the media. An amount of fresh culture medium equivalent to half the volume of the original culture was added to each flask weekly until the colonies were formed. After initial cell growth had occurred, the culture medium was changed every eight days (Tesh \& Modi 1983).

Preparation of chromosomes - A $0.6 \mu \mathrm{g} / \mathrm{ml}$ concentration of colchicine was added to the culture medium for a period of $4 \mathrm{hr}$. Then the monolayer was removed, and the culture media was centrifuged at $1000 \mathrm{~g}$ for $10 \mathrm{~min}$. The supernatant was discarded and $0.56 \% \mathrm{KCl}$ was added to the precipitate. The mixture was stirred by flushing with a Pasteur pipette for $30 \mathrm{~min}$. Then, the mixture was centrifuged again and Carnoy fixative (methanol and acetic acid $3: 1$ ) was added, for $15 \mathrm{~min}$. Three successive washings with Carnoy's were carried out. One $\mathrm{ml}$ of the cell suspension was dropped onto clean slides. The dried preparation was stained with $2 \%$ Giemsa (Schneider 1987, Lee \& Hou 1992).

\section{RESULTS}

Anopheles albimanus - Cellular growth occurred in flasks after a four week incubation period. Individual colonies adhering to the flask were observed after this time. In addition, epithelial-like cells floated in the growth medium. In some flasks, growth stopped and the cells decomposed. In other cultures, the medium was vigorously pipetted and the floating cells were disjoined and later centri- fuged. When transplanted in fresh media, growth restarted within seven days in numerous colonies and formed a monolayer six wecks after the primary culture was started. The optimum $\mathrm{pH}$ range for growth in the MK/VP12 medium was 6.8 to 7.0.

The embryonated eggs which gave the best results were those which underwent a $28 \mathrm{hr}$ incubation period, after oviposition. No cellular growth was observed in MEM, L-15, MM, VP12, MK or MM/VP12.

Aedes taeniorynchus - Cellular growth was obscrved in the MM/VP12 medium three weeks after culture was started. The cell colonies grew at a relatively slow rate during the following three weeks. Vesicles of epithelial-like cells appeared in the fluid medium, or adhered to the substrate around the incipient cell colonics. Some cells melanized and decomposed. Monolayers were formed eight weeks after the embryonic tissue was explanted. The optimum $\mathrm{pH}$ range for the MM/VP12 medium was 6.7 to 7.1 . The embryonated eggs that showed the best results had undergone a $36 \mathrm{hr}$ incubation period. No growth occurred with MEM, L15, MM, VP12, MK and MK/VP12 culture media.

Cellular morphology - The primary cultures of $A n$. albimanus were initially composed of an heterogencous cell population consisting of small spheres, layered epithelial, irregular, gigantic and fibroblastic conformations (Fig.1). Once a monolayer was formed, two more defined cellular shapes were produced. In some flasks with primary cultures, the epithelial-like cells dominated, while in other cultures the fibroblastic cells were more numerous.

In the Ae. taeniorhynchus primary cultures, the majority of cells were small and round, but

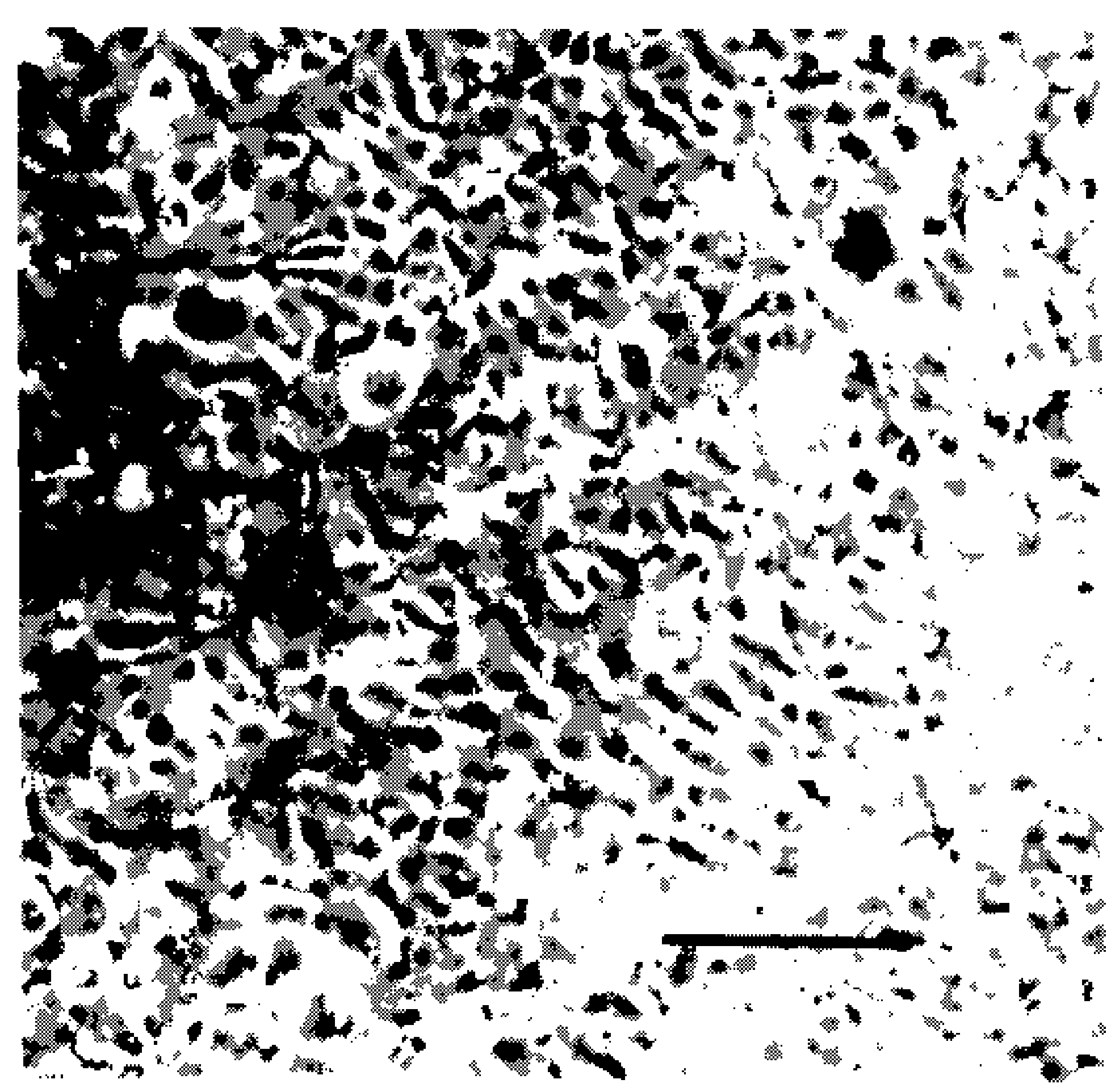

Fig. 1: primary culture from Anopheles albimanus eggs showing heterogenous cellular morphology. Bar $=200 \mu \mathrm{m}$. 
TABI.E

Chromosomic lengths average of Aedes taeniorhynchus

\begin{tabular}{|c|c|c|c|c|c|c|c|c|c|}
\hline & & \multirow[b]{2}{*}{$\mathrm{p}^{*}$} & \multirow[b]{2}{*}{$q^{*}$} & & \multirow[b]{2}{*}{$\mathrm{CI}$} & \multirow[b]{2}{*}{ Met } \\
\hline & & & & $\mathrm{TL}^{*}$ & RL & $q / p$ & $\mathrm{p} / \mathrm{q}$ & & \\
\hline Chromosomes & 1 & $0.63 \pm 0.004$ & $0.63 \pm 0.004$ & $1.32 \pm 0.005$ & 0.27 & 1.0 & 1.0 & 0.47 & 20 \\
\hline Chromosomes & 2 & $0.77 \pm 0.007$ & $0.87 \pm 0.006$ & $1.71 \pm 0.004$ & 0.35 & 1.14 & 0.87 & 0.45 & 20 \\
\hline Chromosomes & 3 & $0.79 \pm 0.003$ & $0.90 \pm 0.005$ & $1.78 \pm 0.005$ & 0.36 & 1.08 & 0.93 & 0.46 & 20 \\
\hline
\end{tabular}

$\mathrm{p}=$ short arm; $\mathrm{q}$ = long arm; $\mathrm{TL}$ - total length; $\mathrm{RL}=$ relative length; $\mathrm{CI}=$ centromeric index; Met. $=$ metaphase; *mean $\pm \mathrm{SE}$

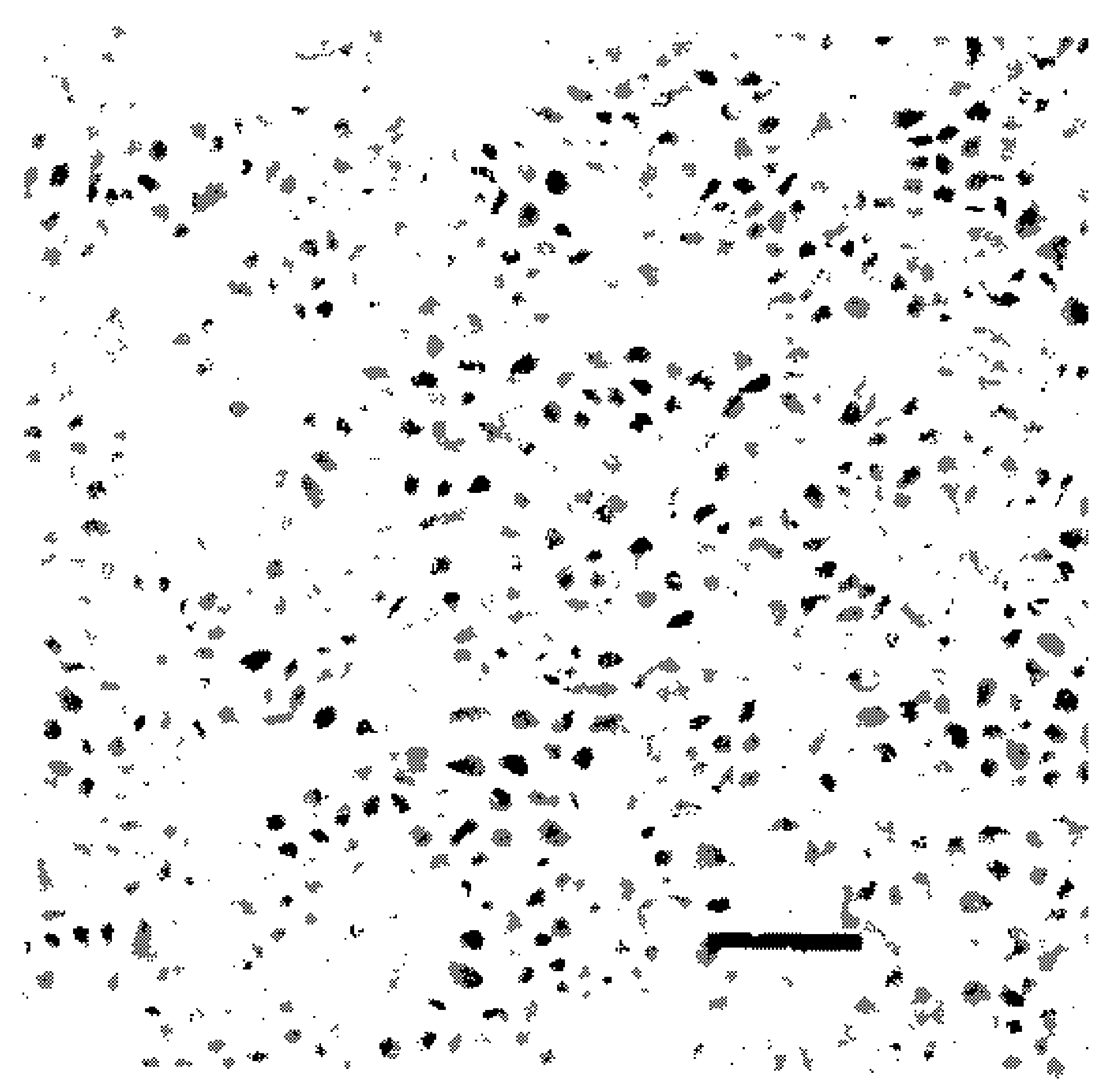

Fig. 2: a monolayer of Aedes taeniorhynchus cells. Bar- 200 $\mu \mathrm{m}$.

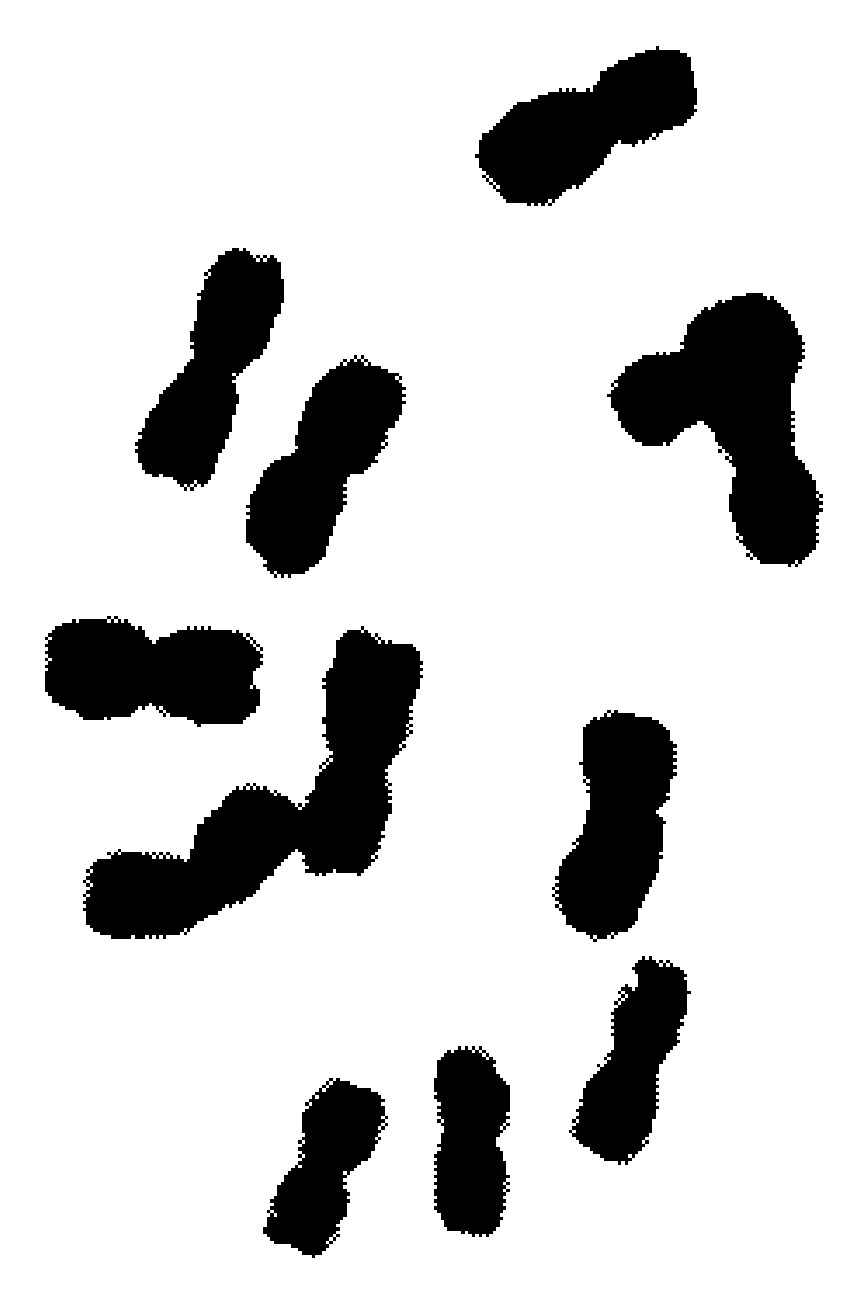

Fig. 4: tetraploid chromosomes from Aedes taeniorhynchus cell in culture, passage 31 .

larger ovoid cells were observed occasionally. This cellular morphology was common in all primary cultures developed from eggs of this species (Fig. 2).

Karyotype of Ae. taeniorhynchus - The metaphases obtained from the primary cell cultures and subcultures at lower passage levels showed six chromosomes as diploid number of the species (three pairs) (Fig.3). The Table shows the average length of the chromosomes. According to their length, they were called 1,2 and 3 in an upward order of size. At higher passage levels a small percentage $(5 \%)$ of tetraploid cells were observed (Fig.4).

\section{DISCUSSION}

With the Ae. taeniorhynchus cells, subcultures have been developed and maintained in laboratory conditions for one year. Serial subcultivation of the cells was carried through 32 passages; some of which have been successfully frozen and stored
Fig. 3: diploid chromosomes from Aedes taeniorhynchus cells in culture 
in liquid nitrogen. However, the An. albimanus primary cultures could not be maintained through subsequent subcultures. Some simply did not grow; others were subcultured in two passages, but became contaminated with yeasts and were discarded.

In the initiation of mosquito cultures a general methodology was used; this was similar to the methodology used in the establishment of mammalian cultures (Hsu et al. 1972). However, for each mosquito species, it was necessary to alter some of the particular conditions, for example, in Ae. dorsalis (Cahoon et al. 1978) the initiation of cell cultures from larvae occurred at first in MM/ VPI2 medium and later, in MM medium, both supplemented with $20 \%$ fetal bovine serum and maintained at temperatures of $26^{\circ} \mathrm{C}$ and $30^{\circ} \mathrm{C}$, respectively. The initiation of the present cell culture of Ae. taeniorhynchus occurred in other conditions, i.e. temperature and medium. The most successful media were MK/VP12 for An. albimanus and MM/VP12 for Ae. taeniorhynchus. This implies that these media provided the necessary nutritive conditions for the explanted tissues to survive as well as for growth of the cells. The $\mathrm{pH}$ range in MK/VP12 medium was narrow, confirming what has been reported in the literature about cells of the genus Anopheles (Hsu et al. 1972), while the $\mathrm{pH}$ range for Ae. taeniorhynchus was relatively larger. The embryonated eggs of $A n$. albimanus and Ae. taeniorhynchus were incubated 28 and $36 \mathrm{hr}$ respectively; $12 \mathrm{hr}$ before being processed, the eggs were maintained at a temperature of $28^{\circ} \mathrm{C}$ in order to stimulate the cellular division. The eggs of Ae. taeniorhynchus were maintained at a temperature of $4^{\circ} \mathrm{C}$ for one night and then incubated at a temperature of $37^{\circ} \mathrm{C}$ for $2 \mathrm{hr}$, according to the process reported by Oelofsen et al. (1990) with Culex (Culex) theileri. The heterogeneous cellular morphology of the primary cultures obtained, mainly in An. albimanus, indicates that several tissue types had initiated growth.

The karyotype of Ae. taeniorhynchus cells, whose diploid number of six, is the same cells of other species of this genus (Ray 1963, Kitzmiller 1976). Pair one was short and metacentrical, while pairs 2 and 3 were submetacentrical and relatively longer. However, the length difference of these last two pairs was not significant. This karyotype is characteristic of all cells at the initiation of the cell culture and also at lower passage levels, while at higher passage levels, tetraploid metaphases were obtained in a small percentage, but the majority of the cells remained diploid. In general, the dipteran cell lines tend to be genetically stable even after many passages in vitro in adequate culture conditions. Kurti and Munderloh (1984) noted that 27 of 33 mosquito cell lines had a modal chro- mosome number of six, two were tetraploid, and four either were not tested or gave equivocal results.

\section{ACKNOWLEDGEMENTS}

To Dr LE Munstermann, Research Scientist, Yale University School of Medicine, for his valuable comments and for reading the original manuscript.

\section{REFERENCES}

Cahoon BE, Hardy JL, Reeves WC 1978. Initiation and characterization of a diploid cell line from larval tissues of Aedes dorsalis (Meigen). In Vitro 14: 255 260.

Freshney RI 1987. Culture of animal cells. A manual of basic technique. Wiley-Liss, 2 nd. ed., New York, $397 \mathrm{pp}$.

Grace TDC 1966. Establishment of a line of mosquito (Aedes aegypti L.) cells grown in vitro. Nature, London $211: 366-367$

Hsu SH, Mao WH, Cross JH 1970. Establishment of a line of cells derived from ovarian tissue of $\mathrm{Culex}$ quinquefasciatus Say. J Med Entomol 7: 703-707.

Hsu SH, Li SY, Cross JH 1972. A Cell line derived from ovarian tissue of Culex tritaeniorhynchus summorosus Dyar. J Med Entomol 9: 86-91.

Igarashi AI 1978. Isolation of a Singh's Aedes albopictus cell clone sensitive to dengue and chikungunya viruses. J Gen Virol 40: 531-544.

Igarashi AI 1985. Mosquito cell culture and study of arthropod-borne togaviruses. Adv Virus Res 30: 21 42.

Kitamura S 1970. Establishment of a cell line from Culex mosquito. Kobe J Med Sci 16: 41-50.

Kitzmiller JB 1976. Genetics, cytogenetics, and evolution of mosquitoes. Adv Genet 18: 315-433.

Kuno G, Gubler DJ, Velez M, Oliver A 1985 . Comparative sensitivity of three mosquito cell lines for isolation of dengue viruses. Bull WHO 63: 279-286.

Kurtti TJ, Munderloh UG 1984. Mosquito cell culture. In K Maramorosch Advances in cell culture. Vol 3, Ed Academic Press, New York, 259pp.

Lee S, Hou RF 1992. Establishment of a cell line derived from embryos of the Diamodback moth, Plutella xylostella (L). J Invertebr Pathol 59: 174-177.

Mitsuhashi J, Maramorosch K 1964. Leafhoper tissue culture: cmbryonic, nymphal and imaginal tissue from aseptic insects. Contrib Boyce Thompon Inst 22: $435-460$.

Munstermann LE 1994. Manual for Mosquito Rearing and Experimental Techniques. Bull. No 5 EJ Gerberg, Dr Barnard, RA Ward (eds). Am Mosquito Contr Assoc, Lake Charles. Lousiana, USA p. 1-2.

Oelofsen MJ, Gericke A, Smith MS, De K Van der Linde TC 1990. Establishment and characterization of a cell line from the mosquito Culex (Culex) theileri (Diptera: Culicidac) and its susceptibility to infection with arboviruses. J Med Entomol 27: 939-944.

Oro G 1984. Establishment of a mosquito cell line from Haemagogus equinus larvae. In Vitro 20: 153-156. 
Rai KS 1963. A comparative study of some mosquito karyotypes. Ann Ent Soc Amer 56: 160-170.

Rowley WA, Dorsey DC, Knowless MA 1984. The replication of two californica serogroup viruses in cell line from the mosquito Aedes triseriatus (Diptera: Culicidae). J Med Entomol 21: 501-506.

Schneider I 1969. Establishment of three diploid cell lines of Anopheles stephensi (Diptera: Culicidae). $J$ Cell Biol 42: 603-606.

Schneider I 1987. Preparation and maintenance of arthropod cell cultures: Diptera, with emphasis on mosquitoes, p.25. In CE Yunker. Arboviruses in arthropod cells in vitro, Vol. 1. CRC, Boca Raton Fl.

Sieburth PH, Maruniak JE 1988. Growth characteristics of a continuous cell lines from the velvetbeau caterpillar, Anticarsia gemmatalis Hubner (Lepidoptera: Noctuidae). In Vitro Cell Dev Biol 24: 195198.

Singh KRP 1967. Cell culture derived from larvae of Aedes albopictus (Skuse) and Aedes aegypti (L). Curr Sci 36: 506-508.
Tesh RB 1980. Establishment of two cell lines from the mosquito Toxorhynchites amboinensis (Diptera: Culicidae) and their susceptibility to infection with arboviruses. J Med Entomol 17: 338343.

Tesh RB, Modi GB 1983. Development of a continuous cell line from the sand fly Lutzomyia longipalpis (Diptera: Psychodidae), and its susceptibility to infection with arboviruses. J Med Entomol 20: 199-202.

Varma MGR, Pudney M 1969. The growth and serial passage of cell lines from Aedes aegypti (L) larvae in different media. J Med Entomol 6: 432-439.

Varma MGR, Pudney M 1971. Anopheles stephensi V. mysacarensis: Establishment of a larval cell line (Mos. 43). Exp Parasitol 29: 7-12.

Varma MGR, Pudney M, Leake CJ 1974. Cell lines from larvae of Aedes (Stegomyia) malayensis and Aedes pseudoscutellaris (Theobald) and their infection with some arboviruses. Trans $R$ Soc Trop Med Hyg 68: 374-382. 